\title{
Studi Resepsi Mahasiswa Broadcasting Universitas Mercu Buana Pada Film Journalism “Kill The Messenger”
}

\author{
Ahmad Toni dan Dwi Fajariko \\ Fakultas Ilmu Komunikasi Universitas Budi Luhur \\ ahmad.toni@budiluhur.ac.id dan riko.fajar@rocketmail.com
}

\begin{abstract}
This study seeks to reveal receptions university student broadcasting beacon globe on film journalism. The purpose of this study to determine the meaning construction contents journalism-themed films through the movie shows them. The relations of meaning to the theme of movies they watch give you an idea about their opinions on the meanings contained in the movie scene. This study uses analysis reception Stuart Hall stated on the three main elements of meaning that is, the dominant meaning, the opposition of meaning and significance negotiations conducted by the subject studied. Construction of meaning built by the subject of research conducted with data triangulation technique, namely written questionnaires, interviews and discussions after watching the film so we get a more comprehensive picture of signification. The results showed that there are different meanings in one scene to scene ten dominated the meaning opposition to the meanings that awakened nature did the film. Next is the meaning of meaning on meaning construction negotiations in the tenth scene. Meaning become dominant meaning that does not give meaning to the subject of study of journalism movie theme.
\end{abstract}

Keyword: reception studies, film journalism, kill the messenger.

\begin{abstract}
Abstrak
Penelitian ini berupaya untuk mengungkapkan resepsi mahasiswa broadcasting universitas mercu buana pada film jurnalistik, tujuan penelitian ini untuk mengetahui konstruksi makna isi film bertema journalism melalui tayangan film yang ditonton mereka, relasi pemaknaan dengan tema film yang mereka tonton memberikan gambaran tentang pendapat mereka pada makna-makna yang terdapat di dalam scene film. Penelitian ini menggunakan metode analisis resepsi Stuart Hall yang dinyatakan pada tiga elemen utama pemaknaan yakni, dominan makna, oposisi makna dan negosiasi makna yang dilakukan oleh subjek yang diteliti, konstruksi makna yang dibangun oleh subjek penelitian dilakukan dengan teknik triangulasi data, yakni daftar pertanyaan tertulis, wawancara dan diskusi setelah menonton film sehingga didapatkan gambaran pemaknaan yang lebih menyeluruh. Hasil penelitian menunjukan bahwa terdapat perbedaan pemaknaan pada scene satu hingga scene sepuluh yang didominasi pada pemaknaan opisisi terhadap makna-makna yang terbangun did alam film, pemaknaan berikutnya ialah pemaknaan negosiasi terhadap makna yang dibanun di dalam kesepuluh scene, pemaknaan dominan menjadi pemaknaan yang tidak memberikan arti kepada subjek penelitian terhadap tema film journalism.
\end{abstract}

Kata Kunci: studi resepsi, film journalism, kill the messenger. 


\section{Pendahuluan}

Film mampu memberikan hiburan, pengetahuan dan pesan. Hal ini berlaku baik untuk film Indonesia maupun film dari luar negeri. Saat ini industri perfilman Indonesia sudah mulai berkembang, film-film Indonesia dianggap layak untuk disaksikan oleh masyarakat Indonesia di samping banyaknya film-film asing yang masuk ke Indonesia. Semakin berkembangnya dunia perfilman Indonesia juga membuat film-film Indonesia menjadi lebih baik. Hal tersebut juga dipengaruhi oleh semakin majunya pola pikir masyarakat Indonesia. Film sebagai karya seni sering dimaknai sebagai hasil cipta karya cipta manusia yang memiliki kelengkapan dari beberapa unsur seni untuk memenuhi kebutuhan yang bersifat spiritual. Dalam hal ini unsur seni yang terdapat dan menunjang sebuah karya film adalah: seni rupa, seni fotografi, seni arsitektur, seni tari, seni puisi sastra, seni teater, seni musik (Nugroho dan Herlina, 2015). Film sebagai karya seni mampu memberikan berbagai macam pengetahuan, baik informasi, pendidikan, hiburan hingga informasi kesehatan, narasi film diformulasikan secara artistik dengan pendekatan hiburan, film mengandung unsur pesan berupa tanda yang dinegosiasikan kepada penonton melalui fungsi hiburannya. Nugroho dan Herlina (2015) menyatakan pada penghujung tahun 1900 masyarakat Hindia Belanda kembali dikejutkan oleh berbagai iklan di surat kabar yang memberi tajuk 'pertunjukan besar yang pertama'. Sejak saat ini sejarah seni pertunjukan baru dimulai, yang tidak lain adalah film.

Salah satu film yang banyak disaksikan khalayak adalah film "Kill The Mesengger" yang di sutradarai oleh Michael Cuesta dan diproduseri oleh Scott Stuber, Jeremy Renner, dan Naomi Despres. Film dari Amerika ini diangkat dari kisah nyata pemenang pulitzer prize-winning journalist, Gary Webb, film ini bercerita tentang pekerja media yang mengungkap keburukan agen Central Intelligence Agency (CIA) Amerika Serikat terkait dengan konspirasi penyelundupan obat bius dan perdagangan senjata di Nikaragua.

Peneliti mengambil film Kill The Messenger untuk penelitiannya karena film yang berceritakan tentang seorang jurnalis masih jarang diproduksi di dunia perfilman, padahal banyak cerita tentang jurnalis atau wartawan yang dapat dibuat menjadi sebuah film. Selain itu, penulis juga berkeinginan untuk mencari tahu pemaknaan mahasiswa khususnya konsentrasi Broadcasting angkatan 2012 Fakultas Ilmu Komunikasi Universitas Mercu Buana pada kejujuran jurnalis Gary Webb dalam film Kill The Messenger ini. Dalam film yang berceritakan berdasarkan kisah nyata tentang seorang wartawan atau reporter yang berjuang mengungkap dan memberitakan keterlibatan badan intelijen pusat dalam mengimpor kokain. Selain itu film ini juga sesuai dengan bidang peneliti yaitu, Broadcast Journalism. Maka dari itu penulis melakukan penelitian untuk mengetahui bagaimanakah "Pemaknaan Mahasiswa Konsentrasi Broadcasting Angkatan 2012 Fakultas Ilmu Komunikasi Universitas Mercu Buana Pada Keberanian dan Kejujuran Jurnalis Gary Webb Dalam Film "Kill The Messenger". 
Film

Karakteristik film sebagai usaha bisnis seni pertunjukan dalam pasar industri mencakup segala hal permasalahan, dalam sejarahnya film mempunyai tiga elemen besar (Effendy, 2002) diantaranya:

1. Pemanfaatan film sebagai alat propaganda. Film ialah sebagai upaya pencapaian tujuan nasional dan masyarakat. Hal ini berkaitan dengan pandangan yang menilai bahwa film memiliki jangkauan, realisme, pengaruh emosional, dan popularitas. Bauran pengembangan unsur pesan dengan hiburan sebenarnya sudah lama diterapkan dalam kesusastraan dan drama (teater) namun unsur film jauh lebih sempurna dibandingkan dengan teater dari segi jangkauan penonton tanpa harus kehilangan kredibilitasnya.

2. Munculnya beberapa aliran film diantaranya drama, dokumenter, dokudrama dan lain-lain.

3. Memunculkan aliran dokumentasi sosial. Di samping itu, terdapat unsurunsur ideologi dan propaganda yang terselubung dalam suatu film yang berasal dari fenomena yang tampaknya tidak tergantung pada ada atau tidaknya kebebasan masyarakat. Fenomena ini berakar dari keinginan untuk merefleksikan kondisi masyarakat.

Dalam melihat dan mengkaji isi media, banyak penelitian telah dilakukan dengan menggunakan berbagai perspektif teoritis, Gans (1979) dan Gitlin (1980) mengkasifikasikan pendekatan ini ke dalam beberapa kategori, yaitu:

1. Isi media merefleksikan realitas sosial dengan sedikit atau tanpa distorsi. Pendekatan "mirror" ini beranggapan bahwa apa yang disiarkan media merupakan refleksi akurat tentang kenyataan sosial kepada audiens. Pendekatan "null effects", juga beranggapan bahwa isi media menggambarkan kenyataan, namun kenyataan disini merupakan hasil kompromi antara yang menjual informasi ke media dan yang membeli. Realitas kompromi ini kemudian menjadi bagian refleksi atas realitas di luar dan menjadi bagian dari realitas media itu sendiri.

2. Isi media dipengaruhi oleh sosialisasi dan sikap para pekerja media. Pendekatan "communicator centered" mengatakan bahwa faktor psikologis pekerja media (seperti profesionalisme, sikap politik, dan lainnya) membuat para pekerja media memproduksi realitas sosial dimana terdapat norma ikatan sosial, ide, atau perilaku yang "berbeda" diasingkan. Sosialisasi ini berhubungan erat dengan latar belakang yang dimiliki oleh pelaku media. Dalam hal ini pelaku yang dimaksudkan ialah para pembuat film baik produser, kameramen, penata cahaya, penata artistik, penulis naskah, editing, terutama sutradara yang mempunyai kewenangan penuh atas suatu karya film.

3. Isi media dipengaruhi oleh rutinitas isi media. Pendekatan ini menyatakan bahwa isi media dipengaruhi oleh bagaimana para pekerja media dan perusahaan mengorganisasikan dirinya. Misalnya, ketika seorang sutradara film yang melalui karyanya rutin dan kontinu mepresentasikan tema perempuan, politik, persahabatan, budaya, anak-anak dan sebagainya. 
4. Isi media dipengaruhi oleh institusi sosial dan tekanan lainnya. Menurut pendekatan ini, faktor-faktor eksternal seperti ekonomi, tekanan budaya dan audiens ikut menentukan isi. Dalam hal pemodalan media film lebih ditentukan oleh produser sebagai penyandang dana dalam berproduksi sehingga istitusi Production House atau rumah produksi lebih banyak memberikan arahan tentang isi atau content cerita.

5. Isi merupakan fungsi dari posisi ideologi dan fungsi mempertahankan status quo. Pendekatan teori hegemoni mengatakan bahwa isi media dipengaruhi oleh ideologi para pemilik kekuasaan di masyarakat. Media massa membawa ideologi yang konsisten dengan kepentingan para penguasa ekonomi. Para pemilik kekuasaan dalam masyarakat produksi film ialah sutaradara yang mempunyai tanggungjawab moral, material dan lain-lain berkaitan dengan karya film yang dihasilkannya. Latarbelakang pendidikan, organisasi, institusi yang menaunginya membawa ideologi dalam setiap karyanya.

Menurut Lang (Severin \& Tankard: 2008) "media massa memaksakan pada isu-isu tertentu, media massa membangun citra publik tentang figur-figur politik, media massa secara konstan menghadirkan objek-objek yang menunjukan apa yang hendaknya dipertimbangkan, diketahui, dan dirasakan individu-individu dalam masyarakat". Pernyataan ini menunjukan adanya beberapa pengaruh sebagai terpaan pesan yang dikemas media massa untuk mempengaruhi khalayak sebagai perubahan pemikiran baik secara kognitif maupun behavior. Media massa terutama film mampu mengemas pesan untuk menyoroti sejumlah kejadian atau aktivitas masyarakat yang dianggap menonjol, jenis isu film tergantung kepada visi dan misi rumah produksi. Dalam konteks pembicaraan antar individu tokoh cerita media film dapat mempengaruhi persepsi akan pentingnya sebuah isu, di samping dilakukan lewat beberapa simbol yang sifatnya sekunder sebagai bentuk pengemasan pesan. Imbasnya individu-individu yang terlibat dalam komunikasi massa akan dapat berbicara tentang kejadian dan aktivitas aspek cerita film.

Aspek pengaruh diakibatkan oleh pengirim pesan dan penerima pesan, dimana satu sama lainnya terjadi proses pelimpahan dan pembagian makna dalam proses pesan komunikasi. "Aspek pengalaman individual dengan pengalaman kolektif dalam segi pemakaian, sejauh mana hubungan dengan sumber (pesan), posisi pengirim ditinjau dari sudut penerima, dimensi interaktivitas pengirim dan penerima sebagai timbal balik antara pengirim dan penerima" (Denis McQuail: 2000). Dalam penghayatan pangaruh film terjadi proyeksi dan identifikasi, menurut Parensi (2005) "proses identifikasi dinyatakan dalam proyeksi dan identifikasi optik, penonton mengidentifikasi dirinya sebagai cameramen, proyeksi dan identifikasi emosional, di mana perpindahan ruang berlangsung secara logis dan bermotivasi, identifikasi imajiner penonton berkaitan dengan psikologis dan perilaku masing-masing yang diproyeksikan dalam kehidupan sebagai sebuah refleksi dari cerita film. 


\section{Resepsi}

Analisis resepsi merupakan sebuah pendekatan alternatif untuk mempelajari tentang khalayak, bagaimana memaknai pesan yang diterima dari sebuah media, titik awal penelitian ini adalah adanya asumsi bahwa makna yang terdapat di dalam media massa bukan hanya ada pada teks. Teks pada media massa akan memperoleh makna pada saat audiens melakukan penerimaan atau reception. Pada penelitian ini khalayak bisa dikatakan sebagai produsen makna yang aktif, tidak hanya diposisikan sebagai konsumen pada media massa. Reception analysis berfokus pada bagaimana khalayak yang berbeda memaknai isi media tersebut, hal tersebut karena pesan media selalu memiliki banyak makna yang di interpretasikan, dalam proses pemaknaan khalayak akan mendifinisikan informasi yang diterima sesuai sudut pandangnya.

Khalayak merupakan pencipta aktif makna dalam kaitannya dengan teks, sebelumnya mereka membawa kompetensi kultural yang telah mereka dapatkan untuk dikemukakan dalam teks sehingga audien yang terbentuk dengan cara yang berbeda akan mngerjakan makna yang berlainan (Barker, 2013). Makna yang dibaca kritikus dalam teks kultural tidak sama dengan yang diproduksi oleh audien aktif atau pemirsa. Bahkan makna yang diperoleh pembaca yang satu tidak akan sama dengan makna yang diperoleh pembaca lain (Barker, 2013). Penjelasan tersebut menjelaskan bahwa isi dari reception analysis merupakan pesan yang disampaikan melalui media yang dapat dimaknai secara berbeda oleh penerima yang berbeda. Berdasarkan latar belakang yang berbeda dari setiap penerimanya seperti umur, pendidikan, hobi dan pengalaman yang berbeda-beda dapat membuat para remaja ini memaknai pesan secara berbeda pula.

Menurut Stuart Hall yang dikutip dari Eriyanto (2009) ada tiga bentuk pemaknaan antara penulis dan pembaca dan bagaimana pesan itu dibaca di antara keduanya yaitu :

1. Pemaknaan Dominan (Dominan Hegemonic Position), posisi dimana kode yang disampaikan diterima secara umum dan dimaknai secara umum, Tidak terjadi perbedaan penafsiran antara produsen (penulis) dan konsumen (pembaca) pesan.

2. Pemaknaan yang Dinegosiasikan (Negoitated Code atau Position), kode yang disampaikan produsen pesan ditafsirkan secara terus menerus diantara kedua belah pihak. Kode yang diterima khalayak tidak dibaca dalam pengertian umum, tetapi khalayak akan menggunakan kepercayaan dan keyakinan tersebut dan dikompromikan dengan kode yang disediakan oleh produsen pesan.

3. Pemaknaan oposisi (Oppositional Code atau Position), pemaknaan ini terjadi ketika konsumen teks memahami dan menandakan secara berbeda pesan, teks atau kode yang disampaikan oleh produsen dengan kerangka konsep dan ideologinya.

\section{Metode Penelitian}

Penelitian ini menggunakan pendekatan deskriptif analisis, metode ini berguna untuk mengetahui dan memahami pemaknaan penonton film tentang film 
Kill The Messenger maka peneliti menggunakan metode deskriptif analisis. Deskriptif analisis adalah data yang dikumpulkan berupa kata-kata, gambar dan bukan angka, selain itu semua dikumpulkan berkemungkinan menjadi kunci terhadap apa yang sudah di teliti. Peneliti menggunakan deskriptif analisis yaitu data peneliti yang dikumpulkan dari para informan melalui hasil wawancara akan di analisis sesuai dengan masalah pokok penelitian dari analisis tersebut peneliti akan mendapatkan suatu jawaban dari penelitian yang sedang dilakukan..

\section{Hasil Penemuan dan Diskusi}

Adapun hasil yang peneliti dapatkan adalah dengan cara wawancara mendalam pada 7 informan, berikut adalah informan yang terpilih dengan berbagai kriteria yang telah ditentukan antara lain:

Tabel 1. Daftar Informan

\begin{tabular}{cllc}
\hline No & Informan/ jenis kelamin & \multicolumn{1}{c}{ Nama } & Usia \\
\hline 1 & Informan 1/ laki-laki & Agil Anjasmaran & 21 \\
2 & Informan 2/Laki-laki & Ahmad naufal & 22 \\
3 & Informan 3/Laki-laki & Reza Ardian & 21 \\
4 & Informan 4/Perempuan & Novia Andriyani & 23 \\
5 & Informan 5/laki-laki & Yogatama Buchari & 21 \\
6 & Informan 6/Laki-laki & Kurnia Bayu & 21 \\
7 & Informan 7/Perempuan & Helga Ardelia & 21 \\
\hline
\end{tabular}

Tabel 2. Matriks hasil penelitian

\begin{tabular}{lcl}
\hline No & Scene & \multicolumn{1}{c}{ Analisis Pemaknaan } \\
\hline 1 & Scene 1 & $\begin{array}{l}\text { Pemaknaan yang muncul adalah pemaknaan dominan } \\
\text { dan oposisi. } \\
\text { Pemaknaan yang tidak muncul adalah pemaknaan } \\
\text { negosiasi. }\end{array}$ \\
2 & Scene 2 & $\begin{array}{l}\text { Pemaknaan yang muncul adalah pemaknaan dominan } \\
\text { dan negosiasi. }\end{array}$ \\
& & $\begin{array}{l}\text { Pemaknaan yang tidak muncul pada scene ini adalah } \\
\text { pemaknaan oposisi. }\end{array}$ \\
3 & Scene 3 & $\begin{array}{l}\text { Pemaknaan yang muncul adalah pemaknaan dominan } \\
\text { dan oposisi. }\end{array}$ \\
& & $\begin{array}{l}\text { Pemaknaan yang tidak muncul pada scene ini adalah } \\
\text { pemaknaan negosiasi. }\end{array}$ \\
4 & Scene 4 & $\begin{array}{l}\text { Pemaknaan yang muncul adalah pemaknaan dominan } \\
\text { dan oposisi. }\end{array}$ \\
& & $\begin{array}{l}\text { Pemaknaan yang tidak muncul adalah pemaknaan } \\
\text { negosiasi. }\end{array}$ \\
5 & Scene 5 & $\begin{array}{l}\text { Pemaknaan yang muncul adalah pemaknaan } \\
\text { dominan, oposisis dan negosiasi. }\end{array}$ \\
6 & Scene 6 & $\begin{array}{l}\text { Pemaknaan yang muncul adalah pemaknaan } \\
\text { dominan,oposisi dan negosiasi. }\end{array}$ \\
7 & Scene 7 & $\begin{array}{l}\text { Pemaknaan yang muncul adalah pemaknaan dominan } \\
\text { dan opisisi, pemaknaan yang tidak muncul adalah } \\
\text { pemaknaan negosiasi. }\end{array}$ \\
&
\end{tabular}




\begin{tabular}{ccl}
\hline 8 & Scene 8 & $\begin{array}{l}\text { Pemaknaan yang muncul adalah pemaknaan } \\
\text { dominan,oposisi dan negosiasi. } \\
\text { Pemaknaan yang muncul adalah pemaknaan dominan } \\
\text { dan negosiasi, pemaknaan yang tidak muncul adalah } \\
\text { pemaknaan oposisi. }\end{array}$ \\
Scene 9 & $\begin{array}{l}\text { Pemaknaan yang muncul adalah pemaknaan } \\
\text { dominan,oposisi dan negosiasi. }\end{array}$ \\
\hline
\end{tabular}

Pada scene kesatu di atas tujuh informan mempunyai pemaknaan yang berbeda-beda, jika disesuaikan dengan format yang ada mengenai pemaknaan menurut Reception Analysis Stuart Hall terdapat tiga pemaknaan. Pemaknaan yang muncul adalah pemaknaan dominan dan oposisi, pemaknaan yang tidak muncul adalah pemaknaan negosiasi.

Pada scene kedua di atas tujuh informan mempunyai pemaknaan yang berbeda-beda, jika disesuaikan dengan format yang ada mengenai pemaknaan menurut Reception Analysis Stuart Hall terdapat tiga pemaknaan. Pemaknaan yang muncul adalah pemaknaan dominan dan negosiasi, pemaknaan yang tidak muncul pada scene ini adalah pemaknaan oposisi.

Pada scene ketiga di atas tujuh informan mempunyai pemaknaan yang berbeda-beda, jika disesuaikan dengan format yang ada mengenai pemaknaan menurut Reception Analysis Stuart Hall terdapat tiga pemaknaan. Pemaknaan yang muncul adalah pemaknaan dominan dan oposisi, pemaknaan yang tidak muncul pada scene ini adalah pemaknaan negosiasi.

Pada scene keempat di atas tujuh informan mempunyai pemaknaan yang berbeda-beda, jika disesuaikan dengan format yang ada mengenai pemaknaan menurut Reception Analysis Stuart Hall terdapat tiga pemaknaan. Pemaknaan yang muncul adalah pemaknaan dominan dan oposisi, pemaknaan yang tidak muncul adalah pemaknaan negosiasi

Pada scene kelima di atas tujuh informan mempunyai pemaknaan yang berbeda-beda, jika disesuaikan dengan format yang ada mengenai pemaknaan menurut Reception Analysis Stuart Hall terdapat tiga pemaknaan. Pemaknaan yang muncul adalah pemaknaan dominan, oposisis dan negosiasi. Kemudian, pada scene keenam di atas tujuh informan mempunyai pemaknaan yang berbeda-beda, jika disesuaikan dengan format yang ada mengenai pemaknaan menurut Reception Analysis Stuart Hall terdapat tiga pemaknaan. Pemaknaan yang muncul adalah pemaknaan dominan, oposisi dan negosiasi.

Pada scene ketujuh di atas tujuh informan mempunyai pemaknaan yang berbeda-beda, jika disesuaikan dengan format yang ada mengenai pemaknaan menurut Reception Analysis Stuart Hall terdapat tiga pemaknaan. Pemaknaan yang muncul adalah pemaknaan dominan dan opisisi, pemaknaan yang tidak muncul adalah pemaknaan negosiasi

Pada scene kedelapan di atas tujuh informan mempunyai pemaknaan yang berbeda-beda, jika disesuaikan dengan format yang ada mengenai pemaknaan menurut Reception Analysis Stuart Hall terdapat tiga pemaknaan. Pemaknaan yang muncul adalah pemaknaan dominan, oposisi dan negosiasi. Pada scene kesembilan di atas tujuh informan mempunyai pemaknaan yang berbeda-beda, jika disesuaikan dengan format yang ada mengenai pemaknaan menurut 
Reception Analysis Stuart Hall terdapat tiga pemaknaan. Pemaknaan yang muncul adalah pemaknaan dominan dan negosiasi, pemaknaan yang tidak muncul adalah pemaknaan oposisi. Pada scene sepuluh di atas tujuh informan mempunyai pemaknaan yang berbeda-beda, jika disesuaikan dengan format yang ada mengenai pemaknaan menurut Reception Analysis Stuart Hall terdapat tiga pemaknaan. Pemaknaan yang muncul adalah pemaknaan dominan, oposisi dan negosiasi

Setelah mendapatkan hasil penelitian dari wawancara terhadap tujuh informan pada penelitian ini, peneliti akan menguraikan pembahasan mengenai "Bagaimanakah Pemaknaan Mahasiswa Konsentrasi Broadcasting Angkatan 2012 Fakultas Ilmu Komunikasi Universitas Mercu Buana Pada Keberanian dan Kejujuran Jurnalis Gary Webb Dalam Film Kill The Messenger?"

\section{Diskusi}

Pembahasan ini akan menguraikan hasil wawancara mendalam dalam memaknai keberanian dan kejujuran yang diterima pada teks dan bagaimana reception analysis memandang audience tidak pasif dalam memaknai pesan yang dihadirkan dalam teks. Pemaknaan yang dihadirkan pada scene 1 menghasilkan pemaknaan dominan dan oposisi, pemaknaan secara keseluruhan berdasarkan pernyataan Helga, Reza, Novi, Naufal, Agil dan Yoga mempunyai kesesuaian makna. Kesesuaian pemaknaan dominan menjelaskan sikap jurnalis yang baik dalam cara berpenampilan cukup rapi dan seorang jurnalis yang memiliki totalitas dalam melaksanakan pekerjaannya tidak takut dengan halangan yang akan dihadapinya. Sedangkan pemaknaan oposisi yang di utarakan oleh Bayu memandang sikap cara berpakaian seorang jurnalis yang terlalu rapi karena berdasarkan apa yang diliatnya bahwa seorang jurnalis sedikit santai dalam berpakaian pada saat melaksanakan pekerjaannya, pada scene satu ini peneliti tidak menemukan pemaknaan negosiasi berdasarkan pernyataan dari setiap informan.

Pemaknaan yang dihadirkan pada scene 2 menghasilkan pemaknaan dominan dan negosiasi. Pemaknaan secara keseluruhan berdasarkan pernyataan dari Helga, Reza, Agil, Novi dan Naufal memiliki kesesuaian makna pemaknaan dominan mengenai keberanian seorang jurnalis yang mampu mencari informasi yang berasal langsung dari narasumbernya dan sosok yang sangat pemberani walapun harus tertangkap oleh polisi, tetapi demi tuntutan kerja harus tetap melakukannya selain itu juga tidak semua jurnalis berani melakukan hal itu. Pemaknaan negosiasi menurut Bayu dan Yoga menjelaskan untuk seorang jurnalis, Gary webb, sangat berani walaupun harus tertangkap tetapi demi tuntutan pekerjaannya harus melakukannya sampai mendatangi rumah tersangka tersebut dan sampai ikut tertangkap oleh polisi seharusnya Gary Webb lebih mempertimbangkan keselamatan dirinya sendiri. Pada scene kedua ini peneliti tidak menemukan pemaknaan oposisi berdasarkan pernyataan dari setiap informan

Pemaknaan yang dihadirkan pada scene 3 menghasilkan pemaknaan dominan dan oposisi pemaknaan secara keseluruhan berdasarkan pernyataan dari Helga, Reza, Yoga, Novi, Naufal dan Bayu memiliki kesesuaian makna pemaknaan dominan menjelaskan jurnalis yang berani mengambil keputusan yang 
tidak mudah untuk menuliskan berita kepada khalayak walaupun berkaitan dengan pemerintahan dan memiliki resiko yang besar. Pemaknaan oposisi menurut agil menjelaskan sikap dari Gary Webb yang terlalu berani, tidak berfikir panjang untuk karirnya karena berita yang di tawarkan kepada Gary Webb itu menyangkut atau berkaitan dengan pemerintah yang tentunya memegang kekuasaan, pada scene ketiga ini peneliti tidak menemukan adanya pemaknaan negosiasi berdasarkan pernyataan dari setiap informan.

Pemaknaan yang dihadirkan pada scene 4 menghasilkan pemaknaan dominan dan oposisi pemaknaan secara keseluruhan berdasarkan pernyataan dari Reza, Yoga, Agil, Novi dan Naufal memiliki kesesuaian makna. Pemaknaan dominan menjelaskan sikap jurnalis yang berani untuk mendapatkan informasi yang sangat jelas langsung dari saksi atau narasumbernya meskipun itu didalam penjara dan untuk mendapatkan informasi yang sejelas mungkin jurnalis juga harus mendapatkan akses untuk ke dalam penjara itu. Pemaknaan oposisi menurut Bayu dan Helga menjelaskan sikap Gary Webb yang terlalu berani mungkin tidak harus sampai masuk ke dalam penjara karena walaupun memang itu baik agar mendapatkan informasi yang lebih jelas tetapi sikapnya terlalu berani, menurut Helga sikap dari Gary Webb ini dapat menimbulkan dampak negatif. Pada scene keempat ini peneliti tidak menemukan adanya pemaknaan negosiasi berdasarkan pernyataan dari setiap informan.

Pemaknaan yang dihadirkan pada scene 5 menghasilkan pemaknaan dominan dan oposisi, pemaknaan secara keseluruhan berdasarkan pernyataan dari Helga, Reza, Yoga memiliki kesesuaian makna pemaknaan dominan menjelaskan sikap jurnalis yang tidak tanggung-tanggung untuk memperoleh suatu berita dan benar-benar memperjuangkan agar mendapatkan berita yang akurat dan baik, untuk mendapatkan informasi juga sekaligus menguatkan tulisannya yang akan di tulis oleh Gary Webb untuk mengungkap kasus yang akan diberitakan olehnya. Pemaknaan oposisi menurut Novi, Bayu dan menjelaskan sikap jurnalis yang tidak pantas untuk melakukan hal seperti yang dilakukan Gary Webb untuk ikut memberikan pertanyaan. Pemaknaan negosiasi menurut Naufal dan Agil menjelaskan seharusnya Gary Webb tidak melakukan hal seperti itu karena bisa membuat dirinya sendiri mendapatkan masalah dengan sikap dia melakukan hal seperti itu di persidangan yang sedang berjalan.

Pemaknaan yang dihadirkan pada scene 6 menghasilkan pemaknaan dominan, oposisi dan negosiasi, pemaknaan secara keseluruhan berdasarkan pernyataan dari Helga, Reza, Yoga dan Novi memiliki kesesuaian makna pemaknaan dominan menjelaskan sikap berani yang dilakukan oleh Gary Webb karena ingin memberitakan sebuah kasus yang ingin diberitakan jadi dilakukan dengan sepenuh hati sampai datang ke Nikaragua dan menyogok penjaga penjara untuk masuk kedalam penjara tersebut sedangkan itu bukan di negaranya dan juga tidak takut menerima resiko karena ingin mendapatkan informasi yang lebih akurat. Pemaknaan oposisi menurut Bayu menjelaskan tidak setuju dengan sikap Gary Webb ketika masuk ke dalam penjara di Nikaragua sampai memberikan uang sogokan kepada penjaga penjara tersebut karena itu bisa beresiko yang sangat fatal untuk Gary Webb dan itu bukan di negaranya itu bisa mengancam keselamatan Gary Webb. Pemaknaan negosiasi menurut Agil dan Naufal 
menjelaskan Gary Webb ini terlalu berani masuk kedalam penjara di Nikaragua untuk mendapatkan informasi yang benar-benar jelas dan bertemu dengan narasumber yang sudah berada didalam penjara ini tetapi kurang setuju dikarenakan Gary Webb masuk ke dalam penjara dengan cara memberikan uang suap atau menyogok sipir penjaranya, seharusnya Gary Webb nya ini tidak perlu memberikan uang sebagai suap kepada penjaga penjaranya.

Pemaknaan yang dihadirkan di scene 7 menghasilkan pemaknaan dominan dan oposisi. Pemaknaan berdasarkan pernyataan dari Helga, Reza, Yoga, Novi, Naufal, dan Bayu memiliki kesesuaian makna pemaknaan dominan menjelaskan karena kasus ini sangat perlu diungkap dan Gary Webb berani mengambil resiko untuk mengungkap kasus ini dan sudah setengah jalan mencari informasi ke berbagai sumber yang sangat sulit. Informasi yang Gary Webb dapatkan juga informasi yang benar sangat disayangkan apabila berita tersebut dihentikan walaupun agen dari CIA berkata bahwa berita ini hanya suatu kebohongan akan tetapi Gary Webb tetap berani untuk mengungkap berita ini karena menurut Gary Webb berita ini sangat penting untuk dipublikasikan. Pemaknaan oposisi menurut Agil menjelaskan bahwa pilihan yang di ambil oleh Gary Webb adalah pilihan yang salah karena pada akhirnya keberaniannya untuk tetap menuliskan berita itu menimbulkan kekesalan dari pihak yang terkait yang berusaha untuk menghentikan Gary Webb. Pada scene ketujuh ini peneliti tidak menemukan adanya pemaknaan negosiasi berdasarkan pernyataan dari setiap informan.

Pemaknaan yang dihadirkan di scene 8 menghasilkan pemaknaan dominan, oposisi dan negosiasi pemaknaan berdasarkan pernyataan dari Helga, Agil dan Novi memiliki kesesuaian makna pemaknaan dominan menjelaskan sikap yang sudah cukup baik karena untuk seorang jurnalis untuk menulis berita tersebut saja sudah luar biasa karena banyak untuk saat ini jurnalis dalam memberitakan sesuatu itu terkadang di lebih-lebihkan, tetapi Gary Webb benarbenar mengungkap kasus ini dengan sejujur-jujurnya selain itu juga sangat sulit dilakukan karena memberitakan suatu kasus pemerintah yang sangat berkuasa. Pemaknaan oposisi menurut Yoga menjelaskan bahwa kejujuran yang dilakukan oleh Gary Webb sia-sia karena tidak memiliki alat bukti yang menguatkan beritanya tersebut. Pemaknaan negosiasi menurut Naufal, Bayu dan Reza menjelaskan tindakan yang sudah sangat jujur dan sangat baik untuk mengungkap suatu kasus dengan informasi yang didapatkannya seharusnya Gary Webb merekam atau mendokumentasikan pada saat ia mendapatkan informasi dan ketika ia melakukan wawancara untuk menguatkan bukti kalau berita yang ia tulis benar-benar nyata.

Pemaknaan yang dihadirkan di scene 9 menghasilkan pemaknaan dominan. Pemaknaan dominan menurut Novi menjelaskan dikarenakan narasumber tersebut sudah didalam penjara dan apabila narasumber itu mengatakan apa yang terjadi sebenarnya kepada seorang jurnalis dan sampai masuk ke media yang luas, secara tidak langsung narasumber itu mempertaruhkan nyawanya sendiri, narasumber itu juga takut untuk berkata jujur takut dirinya terbawa juga dalam kasus tersebut. Pemaknaan negosiasi menurut Reza, Naufal, Agil, Yoga, Helga dan Bayu menjelaskan Gary Webb seorang wartawan yang baik dan sudah bagus, sudah sangat hebat untuk berkata jujur mengungkap 
Ahmad Toni, Dwi Fajariko : Studi Resepsi Mahasiswa Broadcasting Universitas Mercu Buana Pada Film Journalism "Kill The Messenger"

kebenaran kejujuran yang dilakukan oleh Gary Webb patut diapresiasikan namun ketika narasumber tersebut mengatakan kepada orang lain bahwa tidak pernah bicara kepada Gary Webb ada yang ditakutkan oleh narasumber itu seperti diancam oleh orang orang yang terlibat. Selain itu, Gary Webb tidak mempersiapkan apa yang akan terjadi selanjutnya sehingga pada saat narasumber tersebut mengatakan tidak pernah bertemu dengan Gary Webb, Gary Webb juga tidak memiliki bukti apapun. Seharusnya sebagai seorang jurnalis lebih mendokumentasikan saat mencari informasi tersebut agar tidak dianggap berbohong. Pada scene kesembilan ini peneliti tidak menemukan adanya pemaknaan oposisi berdasarkan pernyataan dari setiap informan.

Pemaknaan yang dihadirkan pada scene 10 menghasilkan pemaknaan dominan, oposisi dan negosiasi, pemaknaan berdasarkan pernyataan dari Helga memiliki kesesuaian makna pemaknaan dominan menjelaskan kejujuran Gary Webb sudah sangat tepat karena sebagai seorang jurnalis yang dibutuhkan adalah kejujuran dalam menyampaikan berita dan apabila dirinya dianggap berbohong itu mungkin karna faktor bahwa dirinya dalam mencari informasi itu tidak memiliki dokumentasi. Pemaknaan oposisi menurut Novi, Agil dan Yoga menjelaskan mungkin semua orang akan berkata yang sama kalau Gary Webb berbohong karena menulis berita itu setidaknya apabila tidak memiliki bukti rekaman atau memiliki bukti lain seperti foto agar semua orang percaya bahwa berita yang ditulisnya itu benar seperti itu adanya. Kejujuran Gary Webb itu seperti sia-sia karena tidak memiliki bukti untuk yang menguatkan, oleh sebab itu Gary Webb dapat dikatakan berbohong karena tidak memiliki bukti apapun dan hanya secara lisan saja. Pemaknaan negosiasi menurut Reza, Bayu, dan Naufal menjelaskan kesalahan fatal yang dilakukan oleh Gary Webb karena tidak merekam atau mendokumentasikan informasi dari narasumber tersebut dan juga tidak memiliki bukti yang kuat seharusnya Gary Webb melakukan dokumentasi dan bisa juga merekam semua informasi yang di dapat dari narasumber agar dapat dipercaya oleh pihak lain atau orang lain.

Dari hasil secara keseluruhan mengenai pemaknaan menurut Stuart Hall ditemukan berbagai macam pemaknaan dominan dari setiap informan, pemaknaan ini hadir karena secara umum keberanian dan kejujuran seorang jurnalis yang ada di dalam film tersebut sudah sesuai dengan sikap yang ada pada jurnalis yaitu, sikap yang berani dalam mengambil keputusan, berani mengambil resiko, berani mencari informasi sedalam mungkin, jujur dalam mencari informasi dan menuliskan berita yang akan di publikasikan, namun pada beberapa scene terdapat juga pemaknaan negosiasi karena dianggap ada beberapa langkah dari jurnalis tersebut yang kurang sesuai dengan informan. Menurut informan seharusnya seorang jurnalis mendokumentasikan atau merekam informasi yang telah didapatkannya melalui narasumber karena hal ini bertujuan agar dapat membuktikan berita yang akan dituliskan benar adanya dan tidak diragukan. Bebeberapa informan juga memaknai keberanian dan kejujuran jurnalis secara oposisi karena menurut beberapa informan sikap jurnalis yang baik itu adalah dengan mengikuti peraturan yang ada bukan untuk melanggar peraturan seperti pada salah satu scene ketika jurnalis Gary Webb ikut dalam persidangan dan memberikan pertanyaan. Selain itu, juga pada scene lainnya ketika Gary Webb 
memberikan uang kepada penjaga penjara agar dapat masuk kedalam penjara tersebut sikap tersebut dapat beresiko untuk karir seorang jurnalis.

Hasil penelitian menjadikan sebuah pemaknaan yang hadir sesuai dengan konteks encoding dan decoding yaitu, pemaknaan decoder (informan) pada pihak encoder (film Kill The Messenger) Stuart Hall yang menjelaskan mengenai setiap pesan yang diterima oleh audience yang dihadirkan dapat dimaknai secara berbeda-beda berdasarkan dominan, negosiasi dan oposisi.

\section{Simpulan}

Berdasarkan penelitian yang didapat dari hasil wawancara mendalam dan mendapatkan semua informasi, maka dapat disimpulkan dari rumusan masalah yaitu bagaimanakah pemaknaan mahasiswa konsentrasi broadcasting angkatan 2012 Fakultas Ilmu Komunikasi Universitas Mercu Buana pada keberanian dan kejujuran jurnalis Gary Webb dalam film "Kill The Messenger" menggunakan analisis Stuart Hall dapat diuraikan berdasarkan pemaknaan dominan, negosiasi dan oposisi. Film Kill The Messenger selain sebagai media hiburan juga dapat memberikan informasi dan juga pengetahuan kepada khalayak tentang keberanian dan kejujuran seorang jurnalis dalam melaksanakan tugasnya yaitu, mencari informasi, melakukan wawancara dan memberitakannya kepada khalayak. Fungsi komunikasi massa dalam film ini juga dapat terlihat yaitu, film sebagai media yang memberikan hiburan dan informasi.

Pemaknaan keberanian dan kejujuran seorang jurnalis yang didapat dari sikap dan cara kerja sebagai seorang jurnalis yang diperankan oleh Jeremy Renner tergambarkan dalam film ini, pemaknaan dominan dari seluruh scene yang dihadirkan menyatakan pernyataan dominan, pemaknaan ini berdasarkan isi dari wawancara yang memberikan pernyataan bahwa seorang jurnalis memang harus berani dalam mencari informasi untuk berita yang akan ditulis dan harus jujur dalam memberitakan informasi yang telah didapatkan kepada khalayak. Pemaknaan negosiasi lebih mengarahkan pemaknaan terhadap jurnalis yang harus lebih perduli terhadap keselamatan dirinya dan orang orang terdekatnya. Selain itu, seorang jurnalis seharusnya melakukan dokumentasi dan memiliki rekaman pada saat mendapatkan informasi dari narasumber. Sedangkan pemaknaan oposisi yang hadir lebih menjelaskan tentang keberanian dan kejujuran jurnalis yang bertentangan dengan sikap jurnalis yang sangat berani dan jujur sehingga tindakan yang diambil tidak mementingkan resiko yang akan didapatkannya.

Pemaknaan yang didapat dari setiap informan memiliki pemaknaan yang bervariasi, hal ini tentu dipengaruhi oleh lingkungan sosial, interpretasi dan latar belakang pendidikan dari informan, dari pemaknaan yang didapat lebih banyak ditemukan pemaknaan yang dominan karena selain film ini berdasarkan kisah nyata dari seorang jurnalis, menurut informan penyajian mengenai keberanian dan kejujuran jurnalis yang terdapat dalam film "Kill The Messenger" sudah sesuai dengan sikap seorang jurnalis. 
Ahmad Toni, Dwi Fajariko : Studi Resepsi Mahasiswa Broadcasting Universitas Mercu Buana Pada Film Journalism "Kill The Messenger"

\section{Ucapan Terima Kasih}

1. Fakultas Ilmu Komunikasi Universitas Budi Luhur, Konsentrasi Broadcast Journalism.

2. Lembaga Penelitian dan Pengabdian Kepada Masyarakat Universitas Budi Luhur.

3. Mahasiswa Broadcasting Universitas Mercu Buana Jakarta.

\section{Daftar Pustaka}

Barker,Chris. (2013). Cultural Studies Teori \& Praktik. Yogyakarta: Kreasi Wacana.

Effendy, Heru. (2002). Mari Membuat Film: Panduan Menjadi Produser. Jakarta: Yayasan Konfiden.

Eriyanto. (2009). Analisis Wacana "Pengantar Analisis Teks Media. Yogyakarta: LKIS Pelangi Aksara.

Focus Features. (n.d.). Sinopsis Kill The Messenger. Retrieved from http://www.focusfeatures.com/kill_the_messenger/synopsis/

McQuail, Denis. (2000). Teori Komunikasi Massa, Suatu Pengantar. Jakarta: Erlangga.

Nugroho, Garin., \& Herlina. S Dyna. (2015). Krisis dan Paradoks Film Indonesia. Jakarta: PT Kompas Media Nusantara.

Parensi, D.A. (2005). Film Media dan Seni. Jakarta: FFTV IKJ.

Severin, Werner J., \& Tankard, James W Jr. (2008). Teori Komunikasi, Sejarah, Metode dan Terapan di Dalam Media Massa. Jakarta: Kencana Prenada Media Group. 